Vol. 8, Issue 8, August 2021

DOI: 10.17148/IARJSET.2021.88102

\title{
Biosorption for Removal of Nitratesand Phosphates: A Review
}

\author{
Ravina $^{1}$, Sunil Chhikara ${ }^{2}$, Parveen Kumar ${ }^{3}$ \\ ${ }^{1}$ PhD scholar- Department of Zoology, Baba Mastnath University, Asthal Bohar, Rohtak, Haryana \\ ${ }^{2}$ Associate Professor, UIET, Maharshi Dayanand University, Rohtak, Haryana \\ ${ }^{3}$ Assistant Professor, Department of Zoology, Baba Mastnath University, AsthalBohar, Rohtak, Haryana
}

\begin{abstract}
Although notable progress is being made by researchers in the development of tenable and advanced water treatment technologies, stillhuge population and increasing water demand present challenges for water field researchers.Among multitude of pollutants, removal of nitrates and phosphates,is one of the most threatening issues of global water contamination. For this, biosorption has been used and analysed extensively. In this review, all different sorbent materials, particularly for nitrates and phosphates, are hereby listed and discussed. A brief proposal has also been made about the development of combination of sorbent materials, for both nitrates and phosphates, so that after usage, these materials can be recycled and reused as a source of nitrates and phosphates for various useful purposes.
\end{abstract}

Keywords- Biosorption, Biosorbent, Nitrates, Phosphates.

\section{INTRODUCTION}

India is continuously struggling to meet its water requirements due to its large population and increasing demand. On an average $1486 \mathrm{~m}^{3}$ water is available per capita annually [1].According to World Resources Institute, India is the $13^{\text {th }}$ most water stressed country [2]. Due to increasing population in India and improper disposal of domestic and industrial waste in water bodies and rivers, there is much decline in fresh water availability. As India is the world's $10^{\text {th }}$ most industrialized country [3], it contributes high percentage of organic, inorganic and toxic pollutants in polluting precious water resources [4]. Untreated wastewater is indiscriminately disposed into streams, which leads to many health problems and poor water quality of the water bodies and groundwater. Nearly six lakh children lost their lives in 2010 due to water borne diseases in India; which is $30 \%$ of the global total [5]. Globally, about 2 million tons of waste are released in water bodies on daily basis which take in waste from domestic, industrial and agricultural fields [6]. We see for the above-described points, there is much needed value of wastewater treatment.

1.1 Nitrates and phosphates in waste water

Researchers have reported a number of different microbial populations, organic and inorganic contaminants in sewage waste water.This review hereby focusses particularly on nitrates and phosphates as both of these are more often used in fertilizers production, poultry farming etc, thus phosphorus and nitrogen concentration are very high in wastewater from agricultural, domestic and industrial field.Nitrates once ingested get reduced to nitrites so possess health problems especially in infants causing methaemoglobin formation resulting in asphyxia [7]. Its high concentration in water also affects thyroid gland in pregnant women [8]. Also, nitrates get easily converted in carcinogenic substances such as Nnitroso compounds by reacting with other chemicals [9]. Phosphate is one of the main causativechemicals, responsible for eutrophication of our precious natural water bodies. Orthophosphate is found as most widely present species of phosphate in municipal and industrial wastewater [10]. According to U.S. Environmental Protection Agency(USEPA), phosphorus concentration in water should be less than $50 \mathrm{mg} \mathrm{L}^{-1}[11,12]$.

\subsection{Removal of nitrates and phosphates}

A number of methods are used for nitrates and phosphates removal as for example, ion exchange resins, precipitation, reverse osmosis, chemical reduction, bioreactor process, magnetic nanoparticles-based method, electrodialysis etc $[13,14,15,16,17]$. These methods have limitations such as low efficiency, narrow range of applicability, high requirement of reagents, generation of toxic wastes during production of regents. Among all these, biosorption method seems to be the most effective alternative for removal and recovery of nitrates and phosphates from wastewater due to its simplicity, high efficiency, ease of implementation, recovery rate, economical characteristics. Also, for and during biosorption no other pollutants are generated [18].

\subsection{Significance of recovery of nitrates and phosphates}

Future uses of nitrates and phosphates after removal and recovery from wastewater (if a cost- effective technique which is operational at large scale is developed) are as following [19].

- $\quad$ use as fertilizer for soil conditioning 
International Advanced Research Journal in Science, Engineering and Technology

Vol. 8, Issue 8, August 2021

\section{DOI: 10.17148/IARJSET.2021.88102}

- $\quad$ use in detergents, cosmetics manufacturer industries

- $\quad$ use in animal feed preparation

- $\quad$ use as a potting material

\section{DISCUSSION}

\subsection{Biosorption and biosorbent}

Biosorption is the method in which biological materials are used to remove unwanted substances from aqueous solution via adsorption. It is a reversible and quick process in which biosorbate ions binds to the functional groups existing on biosorbent surface [20].

\subsection{Biosorbents for nitrates and phosphates}

A number of biosorbent materials are being developed with a broad range of applications in removal and recovery of nitrates and phosphates through biosorption.

\subsubsection{Biosorbents for Phosphates Removal}

Chemically modified ground giant reed has been studied and reported for phosphate sorption [21]. Its sorption capacity was reported $55.7 \mathrm{mg} / \mathrm{g}$. The suitable $\mathrm{pH}$ range for this process was 5-10. Anion exchange resins made from chemically modified soyabean hulls were also considered [22]. Chemically modified sawdust of a fibre crop Aleppo pine is reported for phosphate sorption [23]. Algal species such as, Kappaphycus alverezii, Chlorella vulgaris and Scenedesmus dimorphus are reported for phosphate removal and recovery from wastewater [24]. Cultured Staphylococcus xylosus treated with Fe (III) were used for phosphates biosorption, showed monolayer sorption and impressive recovery rates. Biogenic iron oxide produced by iron oxidising bacteria has been reported for removal of phosphates from aqueous solutions [25].Biochar materials developed by using chemically modified orange peel powder can effectively remove phosphates from water [26]. Activated oyster shells are found to have high phosphate removal capacity [27]. Peat has come as a potential sorbent for phosphate removal from aqueous solutions as it has large surface area and is highly porous and also is abundantly available, so is economical to use [28]. Also, after usage, phosphate rich peat can be used as a source of phosphorus for soil conditioning. Biosorbents have been made from agricultural wastes and by-products called AWBs for removal of phosphates from water [29]. Silica based sorbents also known as Nanostructured Silicates have also been used for phosphate sorption [30]. Corn stalk-based resin having biosorption capacity $40.48 \mathrm{mg} / \mathrm{L}$ and $\mathrm{Zr}$ (IV) loaded orange waste gels having biosorption capacity $175 \mathrm{mg} / \mathrm{L}$ were also reported for phosphate reduction in wastewater samples $[31,32]$.

\subsubsection{Biosorbents for Nitrates removal}

Carbon based adsorbents were studied and unsatisfactory results were reported for nitrate sorption [33]. However, carbon nanotubes, powdered activated carbon, commercial granular activated carbon, show high adsorption of nitrate [34]. Red mud after activation is found to give better results for nitrates removal [35]. A number of novel bacterial strains are being isolated and used for nitrate removal from waste water samples [36, 37,38,39,40]. Chitosan is found as an effective biosorbent for nitrate removal from groundwater, but at the same time it results in turbidity in water [41]. Zeolite coated with chitosan showed maximum results for nitrates removal and best results were observed at 303-313 K [42].Many modifications are also done regarding chitosan beads using epichlorohydrin (ECH) and sodium bisulphate which resulted in enhancing the biosorption capacity. $104.0 \mathrm{mg} / \mathrm{g}$ adsorption capacity was recorded when sodium bisulphate conditioned chitosan beads were used in acidic environment. Fixed bed design was incorporated to support the biosorbent during the process [43]. These chitosan derived biosorbents show economic and many other advantages. $92.1 \mathrm{mg} / \mathrm{g}$ biosorption capacity was reported during laboratory studies [44]. The reason for fine adsorption results was due to interaction between Nitrates (anions) and amine groups (positively charged). Egg shells were also taken for reducing nitrates from waste water samples and these egg shells showed significant nitrate removal capacity [45].Although, seeds of amla, potato flakes, husk of banana, wheat, rice etc were used for nitrate removal of nitrates, but only potato flakes gave significant results in nitrate removal, given contact time of 40 minutes, $51.42 \%$ nitrate reduction was observed [46]. A microalga, Trentepohlia Aurea was also used for sorption of nitrate from wastewater [47]. Chinese reed and bamboo powder are among the novel biosorbents for nitrates sorption. Lignocellulosic agricultural waste materials (LCM) and sugarcane bagasse (BG) are been described well for nitrates removal from aqueous solution by several researchers [48]. Modified wheat straw was studied for nitrates removal from wastewater and fine results were reported [49]. Similarly, rice straw was used and tested as a source of activated carbon in nitrate recovery from artificial water samples [50].

\subsubsection{CommonBiosorbent MaterialsforRemoval of Nitrates and Phosphates}

Phosphate and nitrate removal from wastewater, seem relatable,in some ways [51]. Cross-linked chitosan beads are a leading example of common biosorbent for common biosorbent for both nitrates and phosphates [52]. Its sorption capacity and feasibility of the experiment can be modified and increased, like by protonation of amino group present in chitosan. 
DOI: 10.17148/IARJSET.2021.88102

Table 1. Basic parameters used to study for the development of a specific biosorbent

\begin{tabular}{|c|c|c|c|}
\hline $\begin{array}{l}\text { S. } \\
\text { No }\end{array}$ & Name & Significance & References \\
\hline 1. & Biosorption capacity & $\begin{array}{l}\text { Indicates the concentration of sorbed } \\
\text { biosorbate }\end{array}$ & {$[53]$} \\
\hline 2. & Biosorption efficiency & Refers to the percentage of Biosorption & {$[54]$} \\
\hline 3. & $\begin{array}{ll}- & \text { Gibbs free energy change } \\
- & \text { Enthalpy change } \\
- & \text { Entropy change } \\
\end{array}$ & To determine spontaneity of the process & {$[55]$} \\
\hline 4. & \begin{tabular}{ll}
\multicolumn{2}{l}{ Isotherm Models } \\
- & Langmuir \\
- & Freundlich \\
- & Langmuir- Freundlich \\
- & Reddlich-Petterson \\
\end{tabular} & $\begin{array}{l}\text { To understand mechanism of the } \\
\text { process }\end{array}$ & {$[56]$} \\
\hline 5. & $\begin{array}{ll}\text { Kinetic } & \text { Models } \\
- & \text { Pseudo-first order } \\
- & \text { Pseudo-second order } \\
\text { - } & \text { Intra-particle diffusion }\end{array}$ & Fordesigning of the adsorption system & [57] \\
\hline 6. & Spectrometric analysis (FTIR) & For characterization of the biosorbent & {$[58]$} \\
\hline
\end{tabular}

\section{CONCLUSION}

Nitrates and phosphates are the main pollutants found in domestic and industrial waste water. Main advantages of using biosorption over other conventional methods includes elimination of veryminute quantities of contaminants, cost effectiveness, high efficiency, easy biosorbent regeneration and no additional pollutants formation during the process [59]. Also, non-biodegradable waste can be used in supporting and carrying the biosorbent during treatment. Nanotechnology is being used to upgrade biosorbents for increasing the process efficiency. Researchers are working on Genetically engineered microbial biosorbents having specific affinity and other features for enhancement of biosorption efficiency and its applicability, so in future, more advanced and relevant technologies are hoped to be developed and to be used in waste water treatment [60]. Particular attention is needed to be given to develop more advance material which can be used as a common biosorbent for both nitrates and phosphates removal and recovery from wastewater, so that these can be recycled and used in fertilizer industries. Biosorption should be made operational at domestic level, community level and small industries level, so that recovered nitrates and phosphates loaded on biosorbent can be used in agricultural fields for enhancing soil fertility and in other areas. At large scale with real wastewater sample, main problem is the presence of other pollutants, so more research needs to be done regarding recovery of the phosphates and nitrates at large scale after biosorption. High chemical oxygen demand (COD) of real wastewater samples also create problem. Storage problem which may arise in case of reusability should be emphasized upon. Sorbent beds should be made for assessment of the refined sorbent [61].Biosorption offers a number of advantages over other methods but commercial adoption of biosorption is still lacking in case of nitrates and phosphates.

\section{REFERENCES}

[1]. Per Capita Availability of water-PIB, India, Press Information Bureau, Ministry of Jal Shakti (2020). https://pib.gov.in/PressReleasePage.aspx?PRID=1604871.

[2]. K. Pandey, India world's $13^{\text {th }}$ most water stressed country: WRI. Down to Earth (2019). https://www.downtoearth.org.in/news/water/india-worlds-13th-most-water-stressed-country-wri-66066.

[3]. Annual Report- CPCB, India, Central Pollution Control Board (2009). https://cpcb.nic.in/annual-report.php

[4]. Report-MoEF, Ministry of Environment and Forests (2009). http://www.indiaenvironmentportal.org.in/files/StateofEnvironmentReport2009.pdf

[5]. The state of the World's Children-UNICEF, UNICEF (2012). https://www.unicef.org/reports/state-of-worlds-children

[6]. V.K. Gupta, I. Ali, Environmental Water Advances in Treatment, Remediation and Recycling, (2013)1(1),1-5.

[7]. Report, CEPA, Canadian Environmental Protection Act (1997). https://laws- $\quad$ lois.justice.gc.ca/eng/acts/c-15.31/FullText.html.

[8].The world Health Report, World Health Organization (2005). https://www.who.int/whr/2005/whr2005_en.pdf.

[9]. S.S Mirvish, Role of N-nitroso compoundsand N-nitrosation in etiology of gastric, oesophageal, nasopharyngeal and bladderCancer, Cancer Letter (1995) 93, 17-48. 


\title{
International Advanced Research Journal in Science, Engineering and Technology
}

\author{
Vol. 8, Issue 8, August 2021
}

\section{DOI: 10.17148/IARJSET.2021.88102}

[10]. V.L. Snoeyink, D. Jenkins,Water Chemistry, Wiley (1980).https://www.wiley.com/en-in/Water+Chemistry-p-9780471051961

[11]. U.S. Environmental Protection Agency (USEPA), Quality Criteria for Water, Office of Water, Regulation and Standard, Washington, DC. 20460 EPA (1986)440, 86-001.

[12]. The Florida Legislature,Everglades Protection Area, Florida State Legislature https://fall.law.fsu.edu/collection/FlSumGenLeg/FlSumGenLeg1994.pdf

[13]. F.L. Fu, Q. Wang, Removal of heavy metal ions from wastewaters: a review, J. Environ. Manag (2011)92, 407-418.

[14]. Y.H. Wang, S.H Lin, R.S. Juang, Removal of heavy metal ions from aqueous solutions using various low-cost adsorbents, J. Hazard. Mater (2003)102, 291-302.

[15]. D.W.O Connell, C. Birkinshaw, T.F.O Dwyer, Heavy metal adsorbents prepared from the modification of cellulose: a review, Bioresour. Technol (2008)99, 6709-6724.

[16]. T.A. Kurniawan, M.E.T Sillanpaa, M. Sillanpaa, Nano adsorbents for remediation of aquatic environment: local and practical solutions for global water pollution problems, Crit. Rev. Environ. Sci. Technol (2012)42, 1233-1295.

[17]. N. Galil, M. Rebhun, Primary chemical treatment minimizing dependence on bioprocess in small treatment plants, Water Sci. Technol, (1990)22, 203-210.

[18]. A. Bhatnagar, M. Sillanpaa, Applications of chitin- and chitosan-derivatives for the detoxification of water and wastewater-a short review, Adv. Colloid Interface Sci (2009)152, 26-38.

[19]. L.E. De-Bashan, Y. Bashan, Recent advances in removing phosphorus from wastewater and its future use as fertilizer (1997-2003), Water Res (2004)38, 4222-4246.

[20]. T.A. Davis, B. Volesky, A. Mucci,A review of the biochemistry of heavy metal biosorption by brown algae, Water Research (2003)37, 43114330 .

[21]. X. Xu, B. Gao, Q. Yue, Q. Zhong, Sorption of phosphate onto giant reed-based adsorbent: FTIR, Raman spectrum analysis and dynamic sorption/ desorption properties in filter bed. Bioresour. Technol(2011)102, 5278-5282.

[22]. W.E. Marshall, L.H. Wartelle, An anion exchange resin from soybean hulls, J. Chem. Technol. Biotechnol (2004)79, 1286-1292.

[23]. S. Benyoucef, M. Amrani, Adsorption of phosphate ions onto low-cost Aleppo pine adsorbent, Desalination(2011)275, 231-236.

[24]. L.E. Gonzalez, R.O. Canizares, S. Baena, Efficiency ofammonia and phosphorusremoval from a Colombianagro-industrial wastewater by the microalgae Chlorellavulgaris and Scenedesmus dimorphus, Bioresource Technol (1997)60, 259-262.

[25]. J.A.Rentz, I.P. Turner, J.L. Ullman, Removal of phosphorus from solution using biogenic iron oxides, Water Res (2009)43: $2029-2035$.

[26]. B. Chen, Z. Chen, S. Lv, A novel magnetic biochar efficiently sorbs organic pollutants and phosphate, Bioresource Technol (2011)102, 716723.

[27]. C.W. Lee, H.B. Kwon, H.P. Jeon, B. Koopman,A new recycling

(2009).

https://www.researchgate.net/publication/223589473_New_recycling material_for_removing_phosphorus from water

[28]. S.A. Dean, J.M. Tobin,Uptake of chromium cations and anions by milled peat, Resour. Conserv. Recycl (1999)27, 151-156.

[29]. H. Joosten, D. Clarke, Wise Use of Mires and Peatlands, International Mire Conservation Group and International Peat Society, Saarija rvi, Finland (2002).

[30]. G.M. Atenas, F. Valenzuela,Wastewater Treatment through Low-Cost Adsorption Technologies, Intech(2017) Chapter 40.

[31]. S. Hamoudi, R. Saad and K. Belkacemi, Ind. Eng. Chem. Res (2007)46, 8806.

[32]. B.K. Biswas, K. Inoue, K.N. Ghimire, H. Harada, K. Ohto, H. Kawakita, Bioresour. Technol (2008)99, 8685.

[33]. N.B. Singh,G. Nagpal, S. Agrawal, Rachna, Water purification by using Adsorbents: A Review, Environmental Technology \& Innovation (2018).

[34]. T. Afkhami, Z. Madrakian, Karimi,The effect of acid treatment of carbon cloth on the adsorption of nitrite and nitrate ions, J. Hazard. Mater (2007)144, 427-431.

[35]. M. Bhatnagar, Y.H. Ji, W. Choi, S.H. Jung, S.J. Lee, G. Kim, H. Lee, H.S. Suk, B. Kim, S.H. Min, B.H. Kim, J.W. Jeon, Kang, Removal of nitrate from water by adsorption onto zinc chloride treated activated carbon, Sep. Sci. Technol (2008)43, 886-907.

[36]. R. Du, Y. Peng, S. Cao, C. Wu, D. Weng, S. Wang, J. He,Advanced nitrogen removal with simultaneous Anammox and denitrification in sequencing batch reactor, Bioresour.Technol (2014)162, 316-322.

[37]. S. Ge,Y. Peng, S. Qiu, A. Zhu,N. Ren, Complete nitrogen removal from municipal wastewater via partial nitrification by appropriately alternating anoxic/aerobic conditions in a continuous plug-flow step feed process, Water Res (2014)55, 95-105.

[38]. F. Sun, B. Sun, Q. Li,X. Deng, J. Hu, W. Wu, Pilot-scale nitrogen removal fromleachate by ex situ nitrification and in situ denitrification in a landfill bioreactor, Chemosphere (2014)101, 77-85.

[39]. M. Zhou, Ye. H,X. Zhao, Isolation and characterization of a novel heterotrophicnitrifying and aerobic denitrifying bacterium Pseudomonas stutzeri KTB for bioremediation of wastewater. Biotechnol. Bioprocess Eng.(2014)19, 231-238.

[40]. S. Van den Hende, E.Carre,E. Cocaud,V. Beelen, N. Boon, H. Vervaeren, Treatment of industrial wastewaters by microalgal bacterial flocs in sequencing batch reactors, Bioresour. Technol (2014)161, 245-254.

[41]. Y.Cengeloglu, A. Tor, G. Ersoz, G. Arslan, Removal of nitrate from aqueous solution by using red mud, Sep. Purif. Technol (2006)51, 374378 .

[42]. I.D. Patil, M. Husain, V.R. Rahane,Ground Water Nitrate Removal by Using 'Chitosan' As an Adsorbent, International Journal of Modern Engineering Research (2013)3, 346-349.

[43]. Y. Wang, B.Y Gao, W.W Yue, Q.Y Yue, Preparation and utilization of wheat straw

anionic sorbent for the removal of nitrate from aqueous solution, J. Environ. Sci (2007)19, 1305-1310.

[44]. M. Arora, N.K. Eddy, K.A. Mumford, Y. Baba, J.M Perera, G.W Stevens,Surface modification of natural zeolite by chitosan and its use for nitrate removal in cold regions. Cold Regions Sci. Technol (2010)62, 92-97.

[45]. Y. Xu, N. Chen, C. Feng, C. Hao, T. Peng, Sulphur-based autotrophic denitrification with eggshell for nitrate contaminated synthetic groundwater treatment. Environmental Technology (2016) 37(24), 3094-3104.

[46]. A. Singhal, R. Gupta, A. Singh,Sustainable Bio-Adsorbent for Treatment ofNitrate, Fluoride and TDS in Groundwater. International Research Journal of Pure \& Applied Chemistry (2019)19(1)1-11.

[47]. L. Al-Balushi, N. Rout,Removal of Nitrate from Wastewater Using Trentepohlia Aurea Microalga. Proceedings of the World Congress on Engineering, U.K. (2012). 


\section{International Advanced Research Journal in Science, Engineering and Technology}

Vol. 8, Issue 8, August 2021

\section{DOI: 10.17148/IARJSET.2021.88102}

[48]. S.Chatterjee, S.H. Woo,The removal of nitrate from aqueous solutions by chitosan hydrogel beads, J. Hazard. Mater (2009)164, 1012-1018.

[49]. U.S. Orlando, A.U. Baes, W. Nishijima, M. Okada,A new procedure to produce lignocellulosic anion exchangers from agricultural waste materials, Bioresour. Technol. (2002) 83, 195-198.

[50]. H. Hanafi, S. Azeema,Removal of Nitrate and Nitrite Anions from Wastewater UsingActivated Carbon Derived from Rice Straw, J Environ Anal Toxicol (2016)6, 1-6.

[51]. M.Merzouki, N. Bernet, P.Delgenes, R.Moletta, M. Benlemlih, Biological denitrifying phosphorus removal in SBR: effect of added nitrate concentration andsludge retention time. Water Sci. Technol (2001) 43,191-194.

[52]. A. Sowmya and S. Meenakshi, Effective removal of nitrate and phosphate anions from aqueous solutions using functionalised chitosan beads, Desalin. Water Treat (2014)52(13), 2583-2593.

[53]. J. Cheng, W. Yin, Z. Chang, N. Lundholm, Z. Jiang, Biosorption capacity and kinetics of cadmium (II) on live and dead Chlorella vulgaris, Journal of applied phycology (2017)29, 211-221.

[54]. N. Naggar, R.A. Hamouda, I.E. Mousa, M.S. Abdel-Hamid, N.H. Rabei, Biosorption optimization, characterization, immobilization and application of Gelidium amansii biomass for complete $\mathrm{Pb} 2+$ removal from aqueous solutions, Nature (2018).

[55]. D.A. Faust, O. Ly, Adsorption process for water treatment. London: Butterworths (1987).

[56]. S. Schiewer, B. Volesky, Modeling of multi-metal ion exchange in biosorption. Environ. Sci. Technol (1996)30, 2921-2927.

[57]. D. Suteu, Zaharia, A.C. Alaga, Biosorption- Current bioprocess for wastewater treatment. ResearchGate (2012).

[58]. I. Michalak, M. Mironiuk, K. Marycz, A comprehensive analysis of biosorption of metal ions by macroalgae using ICP-OES, SEM-EDX and FTIR techniques, PLOS ONE (2018).

[59]. E.L.Andersson,Analysis of Various Bioreactor Configurations for Heavy Metal Removal Using the Fungus Penicillium ochro-chloron. Worcester: Worcester Polytechnic Institute (1999)96.

[60]. K. Chojnacka,Biosorption and bioaccumulation-the prospects for practical applications. Environment International (2010)36, $299-307$.

[61]. A. Robalds, L. Dreijalte, O. Bikovens, M. Klavins, A novel peat-based biosorbent for the removal of phosphate from synthetic and real wastewater and possible utilization of spent sorbent in land application, Desalination and Water Treatment (2016)57(28),13285-13294.

[62] Hari Ram G; Asok S.P.; S.LionelBeneston. "Testing of Safe, Barium Free Mixture for Green Flare". International Research Journal on Advanced Science Hub, 3, Special Issue ICITCA-2021 5S, 2021, 89-92. 